\title{
Autopromoción comparativa de la televisión en España: Antena 3 vs Telecinco
}

\author{
Jessica FERNÁNDEZ VÁZQUEZ ${ }^{1}$ \\ Universidad de Vigo
}

\begin{abstract}
RESUMEN:
Con esta investigación, lo que pretendemos es analizar la nueva concepción de las autopromociones en Antena 3 y Telecinco. Si bien es cierto que el enfrentamiento entre las cadenas estaba asegurado desde sus inicios dado sus intereses coincidentes, y hay claros ejemplos de ello a lo largo de su historia, ha sido recientemente cuando se han declarado la guerra por medio de sus autopromociones: ya no sólo intentan promocionar sus contenidos, imagen, etc. sino que ambas tratan de desprestigiar a la cadena rival con alusiones (más o menos explícitas) a su forma de hacer televisión, a sus contenidos, etc.
\end{abstract}

PALABRAS CLAVE: Antena 3; Telecinco; autopromociones; guerra de audiencias; contraprogramación.

TITLE: Comparative autopromotion of the television in Spain: Antena 3 vs. Telecinco

\begin{abstract}
:
In this paper we try to analyze the new conception of autopromotion developed by Antena 3 and Telecinco. The confrontation between they was assured from beginnig because both of channels have the same interests, and there are a lot of examples about this in the history. In this moment, they declare the war of autopromotions: they use this advertising format for discredit the rival channel with allusions (more or less explicit) about the form to do television.
\end{abstract}

KEY WORDS: Antena 3; Telecinco; autopromotion; war of hearing; counter programming.

\section{Introducción}

Tras la aprobación en 1988 de la Ley de Televisión Privada en España nacieron, hacia 1990, las tres televisiones privadas que recibieron la concesión administrativa para comenzar las emisiones: Antena 3, Telecinco y Canal +. Esta nueva circunstancia supuso toda una revolución en el medio televisivo que, influenciado a la vez por la situación de bonanza económica y el aumento de la penetración del medio en la sociedad, pasó formar parte de la rutina diaria de los individuos. Ya no se trataba solo de rellenar tiempo en la televisión, sino que cada canal debía de incluir los mejores contenidos en su programación para abarcar la mayor audiencia posible y

1 Estudiante del Máster de Investigación en Comunicación en la Facultad de Ciencias Sociales y de la Comunicación, Universidad de Vigo. E-mail: jessicafdez@hotmail.com 
convertirse así en líder con el fin de atraer a los anunciantes, principal sustento económico de los canales privados.

Desde sus orígenes, Antena 3 y Telecinco se declararon la guerra como cadenas privadas con un mismo fin, donde el triunfo de una parece suponer la decadencia de la otra, entrando en una situación en la que «todo vale» para ganar. Así, tras años de constantes luchas y estrategias por conseguir el liderazgo, llegamos al punto en el que las autopromociones de las cadenas parecen convertirse en el arma perfecta para desprestigiar, de forma implícita o explícita, al canal rival.

\section{Objetivos, hipótesis y metodología empleada}

Esta investigación tiene por objetivo conocer cómo las principales cadenas de televisión privada en España, Antena 3 y Telecinco, han reinventado las llamadas autopromociones cambiando el concepto que hasta ahora se tenía sobre ellas. Si hasta el momento este formato publicitario se entendía como una forma para difundir la imagen de las cadenas, dar continuidad o informar a los espectadores sobre contenidos dentro de su propia programación, a partir de octubre de 2010 surge una nueva posibilidad en las mismas: desprestigiar a la cadena rival atacando tanto a su imagen como a sus contenidos de una forma más o menos explícita, dando a entender a la audiencia de qué o quién se está hablando.

El segundo de nuestros objetivos consiste en conocer cuál es el origen y cuál se puede considerar un antecedente destacable en este enfrentamiento, para así entender la situación actual. Para ello haremos un breve repaso a la forma de hacer televisión de cada uno de los canales desde su nacimiento.

Así, partimos de las siguientes hipótesis:

- La rivalidad existente entre las cadenas de televisión Antena 3 y Telecinco desde sus orígenes ha virado hasta la actual referencia comparativa entre sí a través de las autopromociones.

- Antena 3 y Telecinco pretenden transmitir una determinada identidad corporativa con el fin de que la audiencia asocie con cada una de ellas unos determinados valores de marca, que se pueden clasificar en cinco categorías ${ }^{2}$ :

- Fidelidad a la marca.

- Reconocimiento del nombre.

- Calidad percibida.

- Asociaciones de la marca adicionales a la calidad percibida.

- Otros activos en propiedad de la marca: patentes, marcas registradas, relaciones con el canal, etc.

2 AAKER D. (1994): Gestión del valor de la marca. Capitalizar el valor de la marca, Madrid, Ediciones Díaz de Santos, 18. 
$\mathrm{Su}$ semejante finalidad y objetivos hicieron que, desde su nacimiento, ambas cadenas buscasen un posicionamiento prácticamente igual, explotando una ventaja competitiva similar. Sin embargo, partimos de la hipótesis de que en la actualidad ambos canales están dejando de lado esa ventaja competitiva semejante intentando diferenciarse a través de sus autopromociones, para, precisamente, posicionarse: Telecinco se basa en la idea del liderazgo, mientras Antena 3 muestra un claro rechazo a la denominada «telebasura».

En cuanto a la metodología empleada, se recuperaron las autopromociones emitidas por ambas cadenas, delimitando la muestra a aquéllas en las que se hacía referencia a la cadena rival; para, finalmente, llevar a cabo un análisis de contenido de las piezas seleccionadas siguiendo pautas semejantes en cada caso con el fin de extraer elementos clave de interpretación. La acotación temporal del trabajo se establece entre octubre de 2010 y enero de 2011.

\section{Antecedentes históricos: breve aproximación a las estrategias de Antena 3 y Telecinco}

El primer canal privado en ver la luz fue Antena 3, que comenzó sus emisiones en enero de 1990. En sus orígenes su programación se vio muy influenciada por el periodismo radiofónico de la emisora de su mismo nombre, siendo sobre todo contenidos con tertulias políticas, debates... dirigidos por profesionales que habían crecido en la radio. Era una cadena que transmitía una imagen seria, con especial dedicación a informativos y cultura.

Por otro lado, el 3 de marzo de 1990 comenzaron las emisiones de Telecinco con un modelo televisivo inspirado en el Canale 5 italiano, con el que compartía dueños. Como señala Vilches, «Telecinco se consolida como la televisiónespectáculo popular con pocas pretensiones culturales o de calidad» $»^{3}$. Su programación tenía el entretenimiento como punto de referencia, dirigiéndose a la clase baja con el fin de alcanzar al número máximo de espectadores ya que ${ }^{4}$ :

El modelo comercial de Tele 5 intenta buscar la máxima audiencia posible, especialmente entre las clases más populares de la población para después vender este público a los anunciantes con una agresiva estrategia de ventas.

Eran dos cadenas con formas de hacer televisión completamente diferentes, pero estas fueron variando según los gustos y preferencias de la audiencia. Si bien el modelo inicial de Telecinco le hizo triunfar en un primer momento tal y como demuestran los

\footnotetext{
VILCHES, L. (1993): La televisión: los efectos del bien y del mal, Barcelona, Ediciones Paidós, 187. ARTERo MuÑOZ, J. P. (2007): Modelos estratégicos de Telecinco (1990-2005), Madrid, Editorial Fragua, 87
} 
índices de audiencia ${ }^{5}$, hacia 1994 su fórmula estaba demasiado explotada, de modo que «el quinquenio 1990-1994 significa para Tele 5 el comienzo, desarrollo y crisis de su propio modelo televisivo» ${ }^{6}$. A partir de este momento los espectadores parecían preferir como canal privado Antena 3, que comenzaba a despuntar gracias a la adaptación y aprendizaje de sus errores iniciales, emitiendo series como «Farmacia de Guardia»o posteriormente «Manos a la obra», «La casa de los líos», etc. Desde Telecinco se apostó por la ficción nacional con series como «Periodistas», «Médico de familia», etc., pero sin dejar de lado su esencia populista y de entretenimiento: «iQué me dices!» (programa de corazón), «Esta noche cruzamos el Misissipi» (late night), pero aumentando también el número de programas dedicados a la información.

En 1998, Telecinco es la cadena generalista que más tiempo dedica a la información incluso por encima de TVE, algo que se puede relacionar con el desarrollo de $\operatorname{ATLAS}^{7}$ (agencia de noticias de la cadena). Apostaron por la ficción tanto propia como extranjera, magacines matinales, late night, etc. y ya en el año 2000 se decantaron por la telerrealidad, la asignatura pendiente de Antena 3: «Gran Hermano» aterrizaba en España. Junto a él, llegaron nuevas ediciones y nuevos formatos del estilo, proliferando el número de espacios y tiempo dedicados a la prensa del corazón y reduciendo el tiempo dedicado a los informativos.

Como canales rivales siguieron empleando estrategias de programación con el objetivo de ganar telespectadores en detrimento del canal rival. A pesar de que la contraprogramación fue regulada imponiendo a las cadenas el establecer con once días de antelación su parrilla ${ }^{8}$, esto no impidió que los canales se enzarzaran en una guerra por este motivo hacia 2004.

\section{De contraprogramación a la «guerra de promos»}

\subsection{Orígenes de la contraprogramación y auge de las autopromociones. Concep- tos clave}

Desde las primeras emisiones de televisión en España en 1956 hasta la aprobación de la Ley del Tercer Canal en 1983, Televisión Española mantuvo el monopolio del sector, por lo que toda la audiencia se concentraba en el canal público y no se puede hablar todavía de «contraprogramación» ante la falta de competencia. Sin embargo, tras el surgimiento de los canales autonómicos y el posterior desarrollo

\footnotetext{
AIMC. EGM 30. Estudio General de Medios 1968-1998. CD-ROM 6.

ARTERO MuÑoz, J. P. (2007), op. cit., 85.

Agencia de noticias ATLAS, ATLAS online, http://www.atlas-news.com/info/quien_somos.shtml. Web visitada el 14/02/2011.

8 REAL DECRETO 1462/1999 de 17 de septiembre de 1999. Reglamento que regula el derecho de los usuarios del servicio de televisión a ser informados de la programación a emitir. http://boe.es/boe/dias/1999/09/29/pdfs/A34660-34662.pdf. Web visitada el 15/02/2011.
} 
de las cadenas privadas a nivel estatal, el sector sufrió grandes cambios que afectaron tanto a la producción como a las horas de emisión y, por supuesto, a la programación ofrecida a la audiencia. Estos hechos hicieron que el término «contraprogramación» comenzase a cobrar vida en España a medida que crecía la competitividad entre los canales declarados rivales.

A pesar de la titularidad pública de TVE, esta competía entonces a nivel publicitario con los canales privados que vieron la luz, como ya vimos, en los inicios de la década de los 90: todos ellos tenían un mismo modelo de negocio centrado especialmente en los ingresos que la emisión de publicidad implicaba, por lo que el total de la audiencia lograda marcaba su rentabilidad. En estos momentos, los canales privados buscaban «atrapar con su programación a la mayor cantidad de público -arrebatándoselo a TVEy retenerlo todo el tiempo frente a su pantalla» ${ }^{9}$. Se materializaba así la competencia entre las cadenas y comenzaba la imparable lucha por la audiencia, ofreciendo cada cual los que consideraban «mejores contenidos» para atraerla y llevarse la mayor parte del pastel publicitario. Se desarrollaron para ello acciones, tanto de marketing estratégico como publicitarias, entre las que destacaba la autopromoción de los espacios. «Desde este momento, la producción de los programas se planificaba teniendo en cuenta la franja horaria en que iban a ser programados» ${ }^{10}$, comenzando a ser habitual el empleo de las estrategias de contraprogramación ${ }^{11}$ :

La contraprogramación es ubicar un programa fuerte (entendemos por programa fuerte aquel programa que ya ha probado su rentabilidad en la misma franja horaria que su competidor o en una franja cercana). También puede considerarse como programa fuerte un programa que, sin experiencia previa en resultados de rentabilidad, permita igualmente prever su competitividad en la franja horaria debido a factores de contenido o promoción en la misma franja que un programa de la competencia, compartiendo ambos el mismo target, de tal manera que la misma audiencia se ve forzada a repartirse entre ambas ofertas; el objetivo de esta estrategia es desestabilizar al programa de la competencia.

Es decir, la contraprogramación se trata de:

Un procedimiento de respuesta al éxito de los programas de la competencia consistente en oponer en la misma franja horaria otros programas con atractivo suficiente como para restar a aquellos parte de su audiencia ${ }^{12}$.

9 MATEOS-PÉREZ, J. (2008): «La contraprogramación y la desprogramación en España (1989-1994). Definiciones, desarrollo y ejemplos», Historia y comunicación social, 13, http://revistas.ucm.es/inf/11370734/articulos/HICS08081101191.PDF. Web visitada el 10/05/2011.

10 Guerrero, E. (2010): El entretenimiento en la televisión española. Historia, industria y mercado, Barcelona, Editorial Deusto, Centro de ILbros PAPF, S.L.U, 60.

11 DANTA, R. (2009): «TV y capitalización del tiempo de ocio. La programación como medio de producción», Revista Latina de Comunicación Social, 64, http://www.revistalatinacs.org/09/ art/47_846_ULEPICC_04/39Danta.html. Web visitada el 09/05/2011.

${ }^{12}$ Mũ̃̃z, J.J. (2004): Nuevo diccionario de Publicidad, Relaciones Públicas y Comunicación Corporativa, Buenos Aires, Editorial Libros en Red, 82. 
Como recoge Bustamante, «la estrategia de programación está diseñada siempre, necesariamente, en función de las estrategias de los competidores, deducida a partir de ellas» ${ }^{13}$. Llegados a este punto y siguiendo a este mismo autor, es necesario aclarar que cuando hablamos de «contraprogramación» no nos referimos solamente a «desprogramación», entendiendo desprogramación como «cambiar la programación previamente anunciada», sino que la «contraprogramación» va más allá y

[...] adopta otros procedimientos más sistemáticos y habituales en la competencia entre operadores televisivos: programa fuerte frente a programa fuerte de los competidores, programa débil en caso de un triunfo ajeno irremediable, programa diferente para públicos complementarios ${ }^{14}$.

Con el tiempo, el público se volvió más exigente y cada canal buscaba una ventaja competitiva que lo posicionase como favorito y, así, lograr fidelizar a una audiencia cada vez más fragmentada ante el aumento de la oferta televisiva. Para ello transmitían una serie de valores intangibles, una marca propia con la que los públicos se identificasen despertando una especie de sentimiento de pertenencia en la mente del receptor. Para ello, los diferentes canales se sirvieron de las autopromociones, término que podemos definir como $^{15}$ :

[...] estrategias publicitarias empleadas por un operador para vender la propia imagen de modo institucional, como canal de televisión en su conjunto, o bien de algún formato en concreto, yendo mucho más allá del simple acto de información a los espectadores.

A su vez, las autopromociones «permiten la imbricación de las señas de identidad del canal y el contenido» ${ }^{16}$, transmitiendo una determinada identidad corporativa e intentando crear en la mente del espectador una determinada imagen con la que identificarse. Estas formas de actuar se mantienen hasta la actualidad, teniendo siempre en cuenta que «el conjunto y peculiaridades de la programación difundida [...] sería el reflejo más exacto y riguroso de su voluntad ideológica, comercial o de cualquier otra índole o intención ${ }^{17}$.

13 Bustamante, E. (1999). La televisión económica. Financiación, estrategias y mercados, Barcelona, Editorial Gedisa, 96

14 Ibidem.

15 DAFONTE, A. «Construcción de marca en formatos televisivos: los jóvenes como objetivo». http://www.unav.es/fcom/cicom/2006/docscicom/4_DAFONTE_GOMEZ.pdf. Web visitada el 10/05/2011

16 SÁNCheZ TENA, J.E.; ORTEGA ANGUlo, S. (2004). «Incógnitas y contradicciones de la programación», El Anuario de la televisión, 2004, Madrid, GECA.

17 Barroso garcía, J. (2002): Realización de los géneros televisivos, Madrid, Síntesis. 


\subsection{Antecedentes recientes}

Si bien es cierto que desde sus orígenes las dos cadenas analizadas sabían que serían rivales, la situación vivida por ambas hoy en día parece tener un claro antecedente en la lucha iniciada en 2004. Como ya dijimos con anterioridad, la contraprogramación llegó a España con el advenimiento de la televisión privada y, pese a que su uso era más habitual de lo debido, pasó a estar en el ojo del huracán en 2004, año en el que Telecinco la empleó en numerosas y sonadas ocasiones: el canal variaba el día de emisión de su exitosa serie «Los Serrano» en función de la programación de sus principales competidoras, TVE1 y, en especial, Antena 3.

En un principio, Telecinco emitía esta serie los martes en primetime, pero la emisión pasó al jueves haciéndola coincidir con la segunda temporada de la serie de Antena 3 «Casi perfectos», superándola en audiencia ${ }^{18}$. Telecinco parecía querer repetir jugada y comenzó una nueva lucha contra este mismo canal, pero esta vez con el objetivo puesto sobre «Aquí no hay quien viva». Hasta abril de 2004, «Los Serrano» tenía asignado el jueves y «Aquí no hay quien viva» los miércoles, situación que cambió a partir del 14 de abril ya que Telecinco pasó su serie a los miércoles sin anunciar sus cambios en la parrilla y convirtiendo a ambas series en rivales. Ese mismo día, Antena 3 emitió «Aquí no hay quien viva» veinte minutos antes de lo previsto y sin un solo corte publicitario algo que, junto al posible desconocimiento del cambio de emisión de la serie de Globomedia, repercutió en un exitoso share para la cadena de Planeta ${ }^{19}$. Pero eso solo ocurrió el primer miércoles, ya que la serie de Antena 3 no pudo superar la audiencia total de la temporada de la exitosa serie familiar ${ }^{20}$. La contraprogramación no le salió barata a Telecinco, ya que el Consejo de Ministros multó al canal con 350.000€, la mayor sanción impuesta a una televisión, por sus constantes prácticas «ilegales» a la hora de pro$\operatorname{gramar}^{21}$. La «guerra de audiencias» siguió vigente mientras se emitían ambas series, hasta que Telecinco se hizo con el 15\% de la productora de José Luís Moreno y puso fin a la vida de «Aquí no hay quien viva» en Antena $3^{22}$.

A pesar de que en septiembre de 2006 se modificó la legislación aprobándose por Real Decreto ${ }^{23}$ una nueva disposición que permite a las cadenas hacer públicos

18 Fórmula TV, http://www.formulatv.com/1,20080105,6482,4.html. Web visitada el 10/02/2011

19 ABC, Abc online, http://www.abc.es/hemeroteca/historico-16-04-2004/abc/Comunicacion/aquino-hay-quien-viva-se-impuso-a-los-serrano-en-una-batalla-sin-reglas-el-virus-esta-de-

vuelta $962984461782 . h t m l$. Web visitada el 10/02/2011

$20^{-}$Fórmula TV, http://www.formulatv.com/1,20050111,743,1.html. Web visitada el 7/02/2011

21 Vertele, http://www.vertele.com/noticias/multa-historica-a-telecinco-por-contraprogramar/. Web visitada el 10/02/2011

22 El Mundo, El Mundo on-line, http://www.elmundo.es/elmundo/2006/06/02/comunicacion/ 1149262300.html. Web visitada el 10/02/2011

23 REAL DECRETO 920/2006, de 28 de julio de 2006. Reglamento general de prestación del servicio de difusión de radio y televisión por cable. http://www.boe.es/boe/dias/2006/09/02/pdfs/A31532-31538.pdf. Web visitada el 15/02/2011. 
los contenidos televisivos con tres días de antelación en lugar de once, las dos cadenas privadas siguen empleando esta estrategia con el fin de lograr el liderazgo.

\subsection{Situación actual: origen y desarrollo}

Programar en base a la parrilla de la cadena rival parece ser la principal estrategia que, desde el inicio de la temporada correspondiente a septiembre de 2010, llevan a cabo Telecinco y Antena 3, aunque esta vez es la cadena del grupo Planeta la que inicia dicha situación.

Si el miércoles 29 de septiembre comenzaba la emisión de la principal apuesta de Telecinco en la temporada, la serie «Tierra de Lobos», Antena 3 aprovechó esta misma fecha para estrenar la mini serie basada en la vida del cantante Raphael, emitiendo el segundo capítulo el miércoles siguiente, haciéndola coincidir de nuevo con la ficción de la principal cadena rival. El día del estreno, «Tierra de lobos» alcanzó un 15,6\% de cuota de pantalla, mientras que «Raphael» llegó al 13,7\%. El miércoles siguiente Telecinco se apuntó casi un 16\% de nuevo, mientras que la serie de Antena 3 perdía una décima ${ }^{24}$. Pero esta lucha no fue un hecho aislado en la temporada, sino que Antena 3 quería restar audiencia a una serie que se podría convertir en el producto estrella de Telecinco. Así, augurando que el final de su serie «El internado» iba a ser un éxito, programó este último capítulo para el miércoles 13 de octubre, coincidiendo de nuevo con la serie rival. Esa noche Telecinco no pudo vencer y «El internado» se hizo con casi un $20 \%$ de share s. $^{25}$.

Insistiendo en la idea de restar audiencia a «Tierra de lobos», Antena 3 estrenó su gran apuesta, la serie de ficción «Hispania», el miércoles 25 de octubre. Esta vez Telecinco no quedó impasible y modificó su parrilla trasladando «Tierra de lobos» para el martes, sustituyéndola por la miniserie «Felipe y Letizia». Finalmente, fue esta última la que se enfrentó con la ficción de Antena 3 el lunes 25 (día en el que la cadena de Planeta adelantó unos minutos su emisión y no emitió anuncios) y el miércoles 27 de octubre.

Es lógico pensar que estamos ante otra de las muchas guerras lideradas por estas dos cadenas, pero este último enfrentamiento no es más que el origen de un constante ataque a través de autopromociones en las que, de forma más o menos directa, ambas cadenas buscan ridiculizar a su principal rival.

Hasta ahora, las autopromociones se encuentran clasificadas como programas de continuidad que $\left\langle\right.$ sirven para difundir la imagen de las cadenas» ${ }^{26}$, sin olvidar, como indica Valderrana Santomé, que ${ }^{27}$ :

24 Fórmula TV, http://www.formulatv.com/noticias/16593/audiencias-tierra-de-lobos-arranca-encima-raphael/. Web visitada el 7/02/2011

25 Fórmula TV, http://www.formulatv.com/noticias/16769/audiencias-el-internado-lidera-holguradespedida-definitiva/. Web visitada el 7/02/2011

26 MEDINA LABERÓN (1998): Valoración publicitaria de los programas de televisión. Pamplona, ediciones EUNSA, 92. 
Los diferentes espacios ofertados desde el canal para la audiencia requieren obligatoriamente una programación y una promoción de los mismos para que sean demandados. [...] Parte de la motivación para ver ese espacio surge de una intensa campaña promocional del canal que hace apetecible un primer contacto para el receptor.

La lucha iniciada con las autopromociones parte desde Telecinco el día después de la emisión del «Hispania-Felipe Vs. Letizia». A pesar de que su miniserie no superó a la ficción de Antena 3, la cadena emitía una autopromoción en la que se declaraba líder del día y de la noche, dando a entender que su miniserie había obtenido mejores resultados que «Hispania». Si bien es cierto que ese día Telecinco fue líder tal y como presumía, jugó con los datos y las imágenes de la autopromoción para mostrar un supuesto éxito de «La noche de Felipe y Letizia» ${ }^{28}$.

En esta primera autopromoción las imágenes que priman se corresponden con fotogramas de la miniserie, acompañados de datos en los que Telecinco se compara directamente con Antena 3 mediante porcentajes y gráficos de barras en los que alude directamente al canal. La «promo» finaliza con un «líderes absolutos» que no deja lugar a dudas.

Si esto sucedió en octubre, el mes siguiente ambas cadenas emitieron autopromociones con menciones a la competencia. Ni Telecinco puso freno a su nuevo sentido de las autopromociones ni Antena 3 permaneció impasible: ambas lanzaron sendas «promos» atacándose mutuamente. Ya en diciembre fue este último canal el que tomó la iniciativa, incitando a Telecinco a responder con una nueva autopromoción.

\subsection{Análisis de las autopromociones}

\subsubsection{Autopromociones en noviembre de 2010}

En este mes Telecinco lanzó una autopromoción de diecisiete segundos de duración para enfatizar que el jueves 11 de noviembre había sido líder de audiencia en el primetime.

Las imágenes se acompañan de una voz en off que recoge que «los jueves, los espectadores eligen de nuevo a Telecinco como primera opción. Telecinco, líder de audiencia de las cadenas comerciales. Deja atrás la tristeza y anímate en Telecinco».

27 VAlDERRAMA SANTOMÉ, M. (2005): «De la paleo a la neotv a través de la autopromoción y la identidad televisiva: El caso de TVG». Área abierta, http://revistas.ucm.es/portal/abrir.php?url=http://revistas. ucm.es/inf/15788393/articulos/ARAB0505130004A.PDF. Web visitada el 10/02/2011

28 ABC, Abc on-line http://www.abc.es/20101026/tv-series/felipe-hispania-letizia-201010261020.html. Web visitada el 10/02/2011 
Desde el primer segundo de la «promo» Telecinco se declara líder de audiencia (fig.1), representándolo mediante una gráfica en la que aparecen dos barras con los logotipos de las cadenas (fig.2): la barra de la izquierda es dedicada al programa de Telecinco «Gran Hermano» y su 19\% de audiencia y la de la derecha representa directamente a Antena 3 y su $8,6 \%$ de audiencia con la película «Edison, ciudad sin ley».

Tras este dato informa no solo de que fue líder del primetime, sino que superó a Antena 3 en audiencia media del día. Recurriendo de nuevo a las gráficas de barras, en la derecha muestra el $16,6 \%$ logrado por Telecinco el día 11 de noviembre, mientras que la barra de la izquierda representa el 10,6\% de Antena 3 (fig.3).

En esta autopromoción se hace alusión directa a Antena 3 con el uso de su logotipo y sus índices de audiencia. Además, la cadena aprovecha los datos de un solo día para declararse «líder de audiencia de las televisiones comerciales», lo que puede percibirse como un liderazgo mucho más genérico.

Con la voz en off se enfatiza y apoya la idea de liderazgo expuesta con datos, además de acabar con un «deja atrás la tristeza y anímate en Telecinco». Esta última frase hace recordar los inicios de Telecinco donde, como ya se citó con anterioridad, el entretenimiento, la diversión y la poca inclusión de programas de corte cultural formaban parte de su identidad. Sin embargo, esa frase de la autopromoción cambia de matiz si tenemos en cuenta que desde varios programas de Telecinco se refieren, de forma implícita, a Antena 3 como «la cadena triste» ${ }^{29}$.

Si bien es cierto que intentan demostrar su liderazgo del jueves con «Gran Hermano», las imágenes que componen la autopromoción recogen fotogramas de varios de sus programas y rostros conocidos, como son las series «CSI», «Tierra de Lobos», «Hospital Central» y «Aída»; concursos como «Pasapalabra» o «Gran Hermano» y personajes como Jorge Javier Vázquez, Mercedes Milá, Ana Rosa Quintana, Christian Gálvez y Jordi González. Todos ellos podrían apoyar la percepción de Telecinco como «líder de audiencia de las televisiones comerciales», además de la idea «deja atrás la tristeza», ya que muchos de ellos aparecen sonriendo y/o realizando un gesto de triunfador (fig.4), independientemente de que esos contenidos que promociona se emitieran o no el día del liderazgo anunciado.

29 El Semanal Digital, http://www.elsemanaldigital.com/articulo.asp?idarticulo=107320\&tema= \&accion $=\&$ mes $=\&$ ano $=$ ref $=$. Web visitada el 10/02/2011 
Fig. 1.

Inicio de la autopromoción de Telecinco

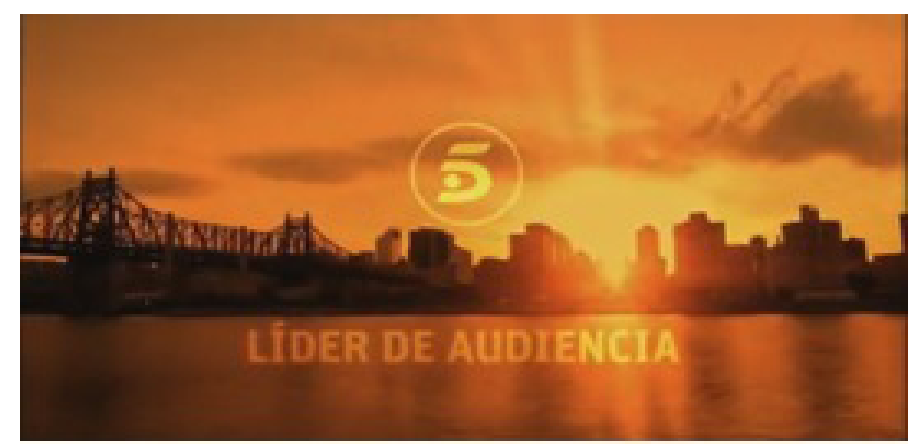

Fig. 2.

Telecinco se compara directamente con Antena 3 en el primetime

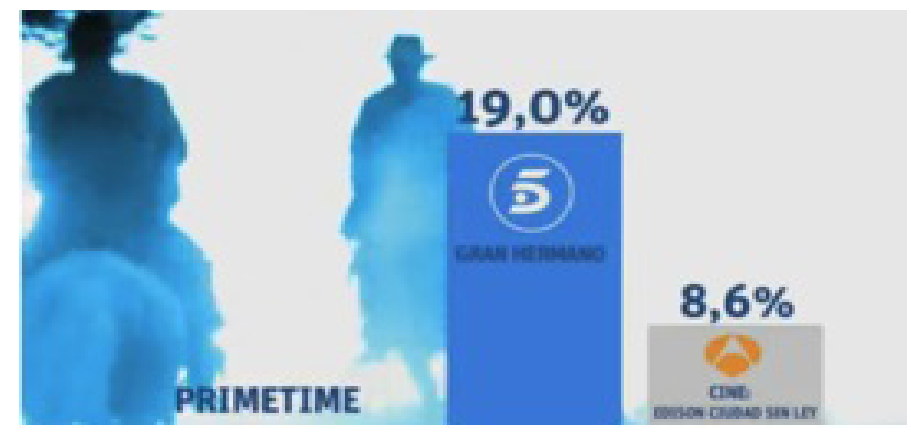

Fig. 3.

Telecinco se compara con Antena 3 en audiencia media del día

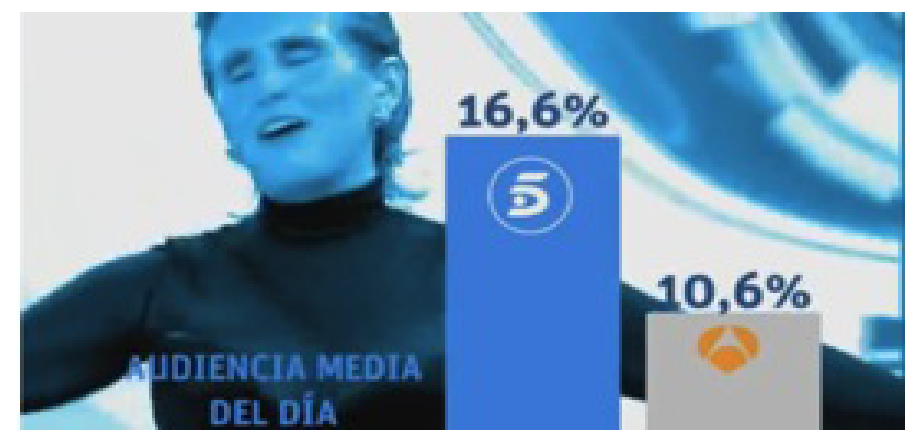

Fig. 4.

Personajes de programas de Telecinco hacen gestos de triunfo

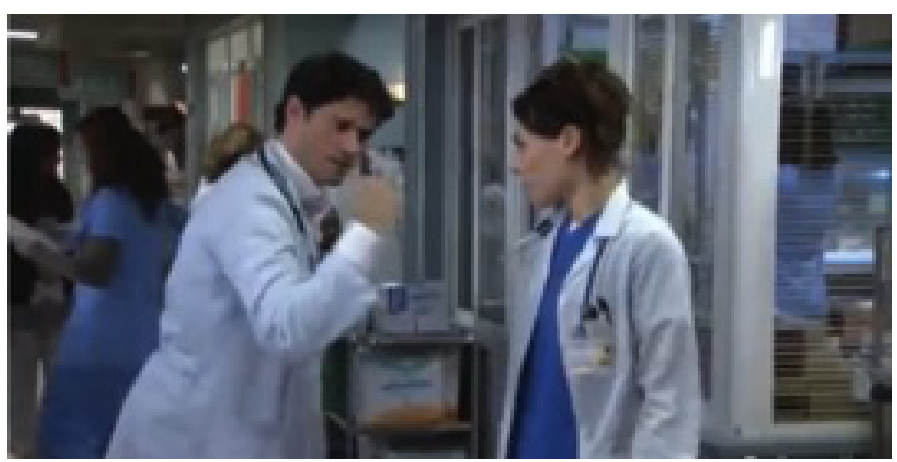


Antena 3 también pasó a elaborar autopromociones con claras alusiones a la competencia. Con veinte segundos de duración, la cadena del grupo Planeta no se remite a gráficos para compararse con Telecinco, sino que se basa en contundentes frases que incluyen implícitamente mensajes que se pueden asociar con la misma. Estas son: «Será porque no ponemos lo mismo mañana, tarde y noche; será porque no gritamos; será porque te respetamos; quizá por eso Antena 3 es la televisión privada que más gusta a los españoles. Gracias».

Si vemos las parrillas de Telecinco, comprobamos cómo esta dedica un alto porcentaje de su tiempo a programas que se encuadrarían en lo que Elías Pérez define como «telebasura» ${ }^{30}$ : «telerrealidad, docu-shows, talk-shows y crónica rosa, negra o amarilla».

En cuanto a las imágenes que componen la autopromoción, aparecen sobre todo presentadores de programas, como es el caso de Karlos Arguiñano, Sandra Daviú, Jaime Cantizano o Jorge Fernández, destacando la aparición de Susana Griso (fig.5) y Matías Prats (fig.6), ambos asociados al periodismo informativo, en el momento en el que la voz en off pronuncia la frase «será porque te respetamos», en una clara y premeditada asociación de contenidos. Series como «Gavilanes»o «Hispania» también tienen unos segundos en la promoción.

En este caso, ante afirmaciones como «Antena 3, la televisión privada que más gusta a los españoles» (fig.7), muestra, a diferencia de su cadena rival, la fuente de la que extraen tal afirmación: barómetro del CIS mayo 2010, dando mayor credibilidad al contenido.

Fig. 5.

La presentadora Susana

Griso en un momento de la autopromoción

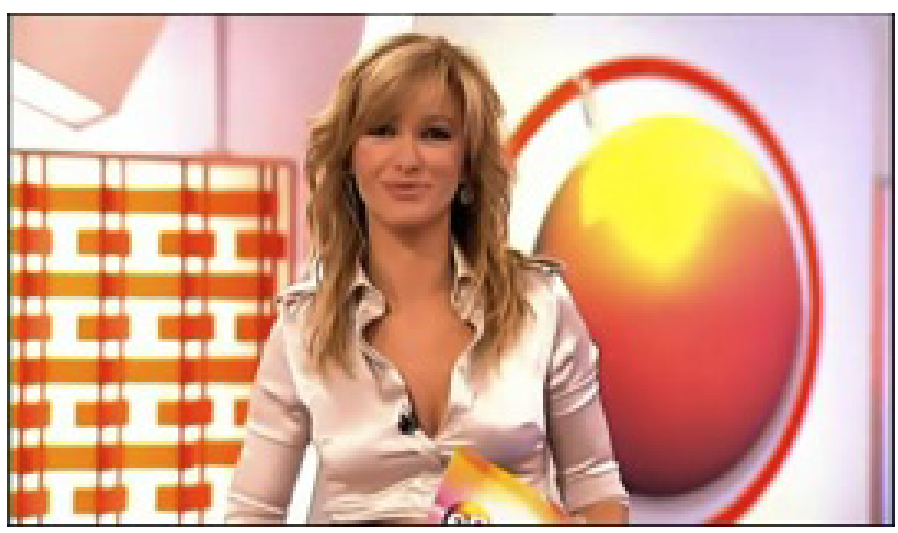


El presentador Matías

Prats en un momento de la autopromoción

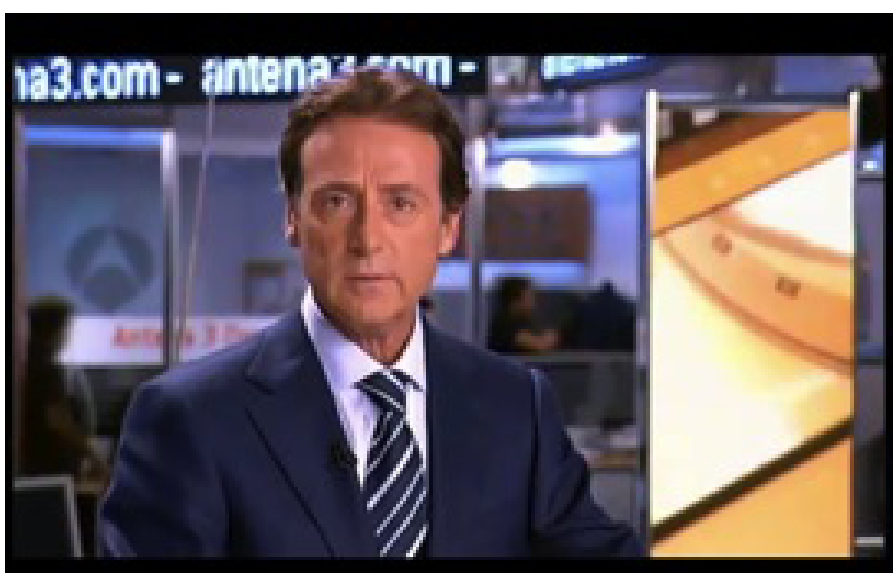

Fig. 7. Antena 3 cierra su autopromoción mostrándose como la cadena que más

gusta

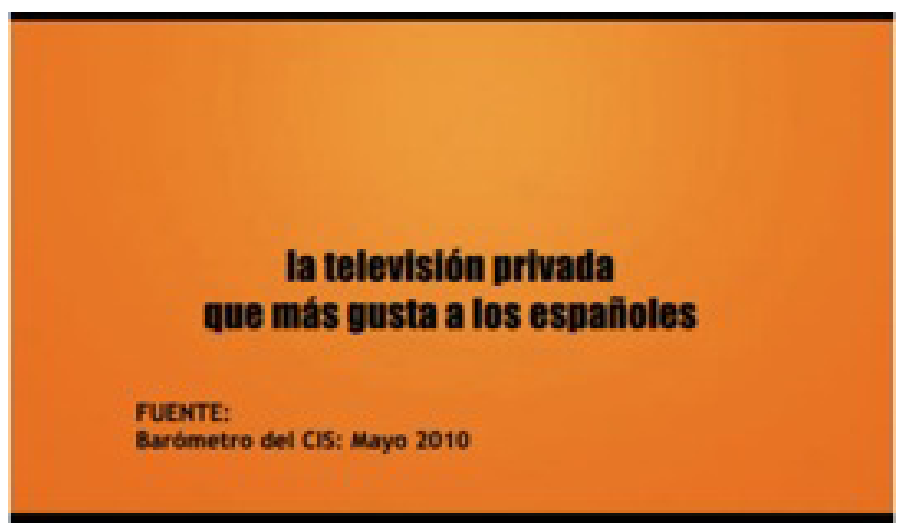

\subsubsection{Autopromociones en diciembre de 2010}

En diciembre de 2010 fue Antena 3 quien tomó la iniciativa emitiendo una autopromoción de tres minutos y medio de duración bajo el título «Pone». Con un formato que recuerda a los musicales, en su producción se contó con la participación de más de 50 rostros conocidos del canal. El estreno se hizo el 29 de diciembre de 2010 a las 22.21 en los tres canales de TDT de forma simultánea.

La autopromoción narra la historia de cómo Antena 3 rechaza una forma de televisión poco seria y de baja calidad. Todo comienza en un despacho (se intuye que de un directivo de Antena 3) planeando una nueva forma de hacer televisión con un profesional que afirma tener una fórmula rompedora, de corte sensacionalista y vulgar. Asustados, sorprendidos y casi sin palabras, desde Antena 3 rechazan esta idea en favor de una televisión de categoría. 
En el musical se juega con la palabra «pone» con un doble sentido: por un lado sintonizar el canal y por otro haciendo referencia a la satisfacción que ver Antena 3 supone al espectador. La letra de su canción dice lo siguiente:

Aquí cualquiera sale, pero aquí no todo vale; ponen los informativos en los que el amarillo no es más que un color; entretenimiento que no humilla a nadie, ruletas que giran hacia un ganador; gente glamurosa, entre otras muchas cosas; los últimos estrenos, pelis que en el cine no pudiste ver; series para todos, héroes y romanos, risas y misterios que hasta acaban bien; gente glamurosa entre otras muchas cosas.

Con estas afirmaciones y a pesar de que la autopromoción es en esencia para promocionar los contenidos de la nueva temporada, Antena 3 no hace referencia directa en ningún momento a sus contenidos concretos (series, concursos...) ni con imágenes ni con palabras, sino que promociona directamente la imagen corporativa del canal. En la «promo» se le ofrece a Jorge Fernández una nueva forma de percibir la televisión, explotando el morbo y en definitiva, el sensacionalismo. Este no da crédito y lo rechaza diciendo que esa no es su «tele» (fig.8 y 9), poniendo a Antena 3 a bailar para mostrar todo su potencial. Antena 3 busca así que la audiencia se forme una imagen corporativa basada en la idea de una televisión de calidad, seria y para toda la familia, insistiendo en que «no todo vale» o «no cualquiera sale». Destaca especialmente el papel de Susana Griso rechazando el amarillismo (fig.10) bajo la frase «donde el amarillo no es más que un color», al referirse a los informativos. El musical se cierra con un «Antena 3 pone» (fig.11). En definitiva, la televisión que Antena 3 rechaza en su autopromoción es la «telebasura», definida como ${ }^{31}$ :

Una forma de hacer televisión caracterizada por explotar el morbo, el sensacionalismo y el escándalo como palancas de atracción de audiencias. Se caracteriza por los asuntos que aborda, alejados siempre de los temas culturales, científicos y artísticos que han definido el progreso del ser humano. Se regodea en los temas zafios, esotéricos y banales [...]. Se define por los personajes que exhibe y coloca en primer plano: son ignorantes, sin sensibilidad ni habilidad demostrada y certificada sobre alguno de los asuntos que ha favorecido el progreso humano: la música, la literatura, la ciencia, el cine o la política [...] y deben ser adalides de la cultura del pelotazo. Deben ser mediocres intelectualmente y pobres culturalmente para que sus argumentos sean seguidos por una gran audiencia cada día menos acostumbrada a esforzarse por entender mensajes procedentes de la televisión.

Si tenemos en cuenta la programación de Telecinco a la que ya se hizo referencia con anterioridad ${ }^{32}$, podemos pensar que existe alguna relación entre sus contenidos y la forma de hacer televisión que Antena 3 rechaza en su autopromoción. Por estas razones, podemos pensar que con esta «promo» Antena 3 esté lanzando un mensaje a su principal rival: mensaje nada objetivo si tenemos en cuenta que programas de su parrilla se podrían incluir en el tipo de televisión que se niegan a hacer.

\footnotetext{
Ibidem., 43

Véase el punto 4.3.1
} 
Jessica Fernández Vázquez

Fig. 8. Jorge Fdez rechaza la idea de televisión sensacionalista que le proponen

Fig. 9. En Antena 3 se avergüenzan de la televisión que les proponen hacer

Fig. 10. Momento del musical donde Susana Griso reniega del amarillismo

Fig. 11. Cierre de la autopromoción con el lema «pone»
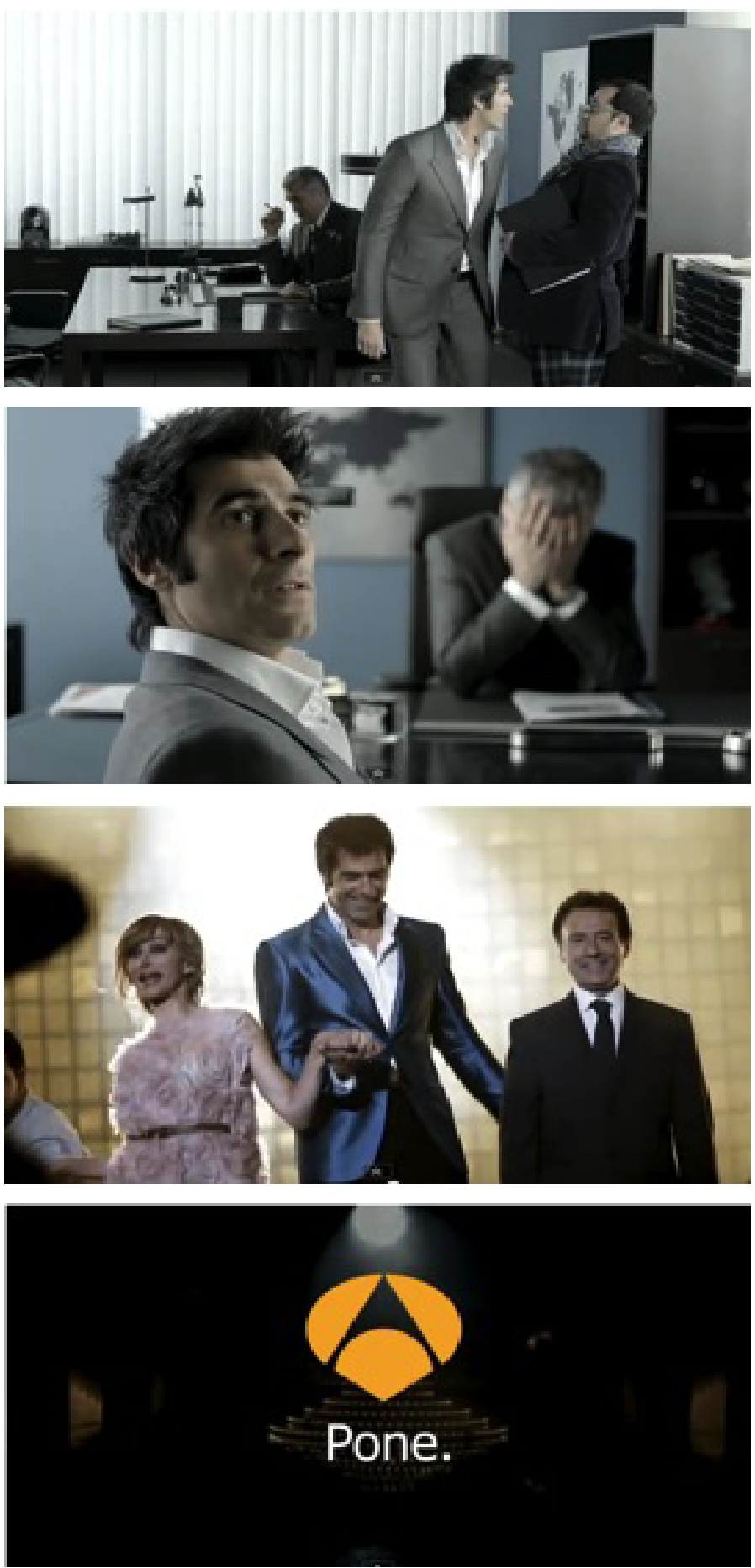
Telecinco, que esta vez no llevaba la iniciativa, se sintió aludida y emitió una autopromoción de treinta y dos segundos de duración respondiendo directamente a la cadena del grupo Planeta jugando, al igual que esta, con la palabra de su slogan «pone» (fig.12) y apoyándose de nuevo en gráficos comparativos para explicar mediante una voz en off lo siguiente:

Telecinco, líder indiscutible en 2010, líder en las mañanas, líder en ficción nacional, líder en entretenimiento y por supuesto líder en informativos. Aunque a algunos no les guste, el dato pone lo que pone, y lo que pone es que tú nos eliges en diversión. En 2011 deja atrás la tristeza y diviértete con nuestra mejor programación. Telecinco la televisión que más gusta, con diferencia.

En esta autopromoción, Telecinco tiene un claro objetivo, que es mostrar a la audiencia su liderazgo tanto a lo largo de todo el año 2010 como en contenidos concretos, utilizando para ello imágenes, gráficos y una voz en off que insiste en la idea (fig.13).

La estructura de la autopromoción recuerda a la que se emitió en noviembre: datos representados mediante gráficos de barras o sectores que muestran en la derecha o en la parte superior la audiencia, siempre en porcentajes, de Telecinco comparada con la de Antena 3, representada en la izquierda o en la parte inferior. En dichos gráficos aparece explícitamente el logotipo de cada canal, por lo que no deja lugar a dudas: por un lado insiste en la idea de liderazgo, mencionando la palabra «líder» hasta cinco veces en bloques temáticos y mostrándola en cada gráfico: entretenimiento, informativos, ficción nacional y franja matinal (fig.14, 15, 16 y 17), además de al inicio y al final de la «promo». Por otro lado, se declara líder de programas concretos que desde el canal denominan entretenimiento («Gran Hermano» y «Sálvame Deluxe» con audiencia por encima de «DEC», programa de corazón de Antena 3), además de dar por supuesto el liderazgo en los informativos.

Las imágenes correspondientes a sus programas o rostros conocidos se intercalan entre los gráficos, siendo destacable que muchas de ellas sean las mismas que las mostradas en la autopromoción de noviembre: Mercedes Milá, Cristian Gálvez, Ana Rosa Quintana o Jordi González, además de utilizar el mismo fragmento de la serie «Tierra de Lobos». También hay fragmentos de la serie «CSI» y «Aída», y, aunque en este último caso la imagen no es la misma que en la «promo» anterior, sí lo es el gesto que realiza el personaje que aparece. Otras imágenes se utilizan de forma novedosa, como es el caso de Jorge Javier y Belén Esteban bailando, Sara Carbonero y Pedro Piqueras trabajando, Pilar Rubio con «OT» e imágenes del Mundial de Fútbol 2010. Es destacable el fotograma que hace referencia a la miniserie «Felipe y Letizia» (fig.18), considerada el origen de este enfrentamiento, en el momento en el que se declara líder de ficción nacional,

La insistencia en el liderazgo es la esencia de la autopromoción, seguida del uso de la palabra «pone» en clara respuesta a la emitida por Antena 3 con anterioridad, dándole al verbo un nuevo significado que se ajusta a la idea que Telecinco quiere destacar: es líder porque lo «pone» el dato. 
Pero estas no son solo las únicas referencias que se pueden asociar con Antena 3 , sino que de forma implícita se insiste una vez más en la idea de «dejar atrás la tristeza», recordando la manera en la que ciertos personajes de Telecinco denominan de forma encubierta al canal de Planeta. Además, el cierre de la autopromoción, «Telecinco la televisión que mas gusta, con diferencia», juega con el dato que Antena 3 mencionaba en su «promo» de noviembre, en el que se declaraba como «la televisión privada que más gusta a los españoles».

Fig. 12. Momento de la autopromoción donde Telecinco usa el mismo eslogan que A3

Fig. 13. Gráfico en el que Telecinco se muestra líder de 2010

Fig. 14. Gráfico en el que Telecinco se declara líder en entretenimiento

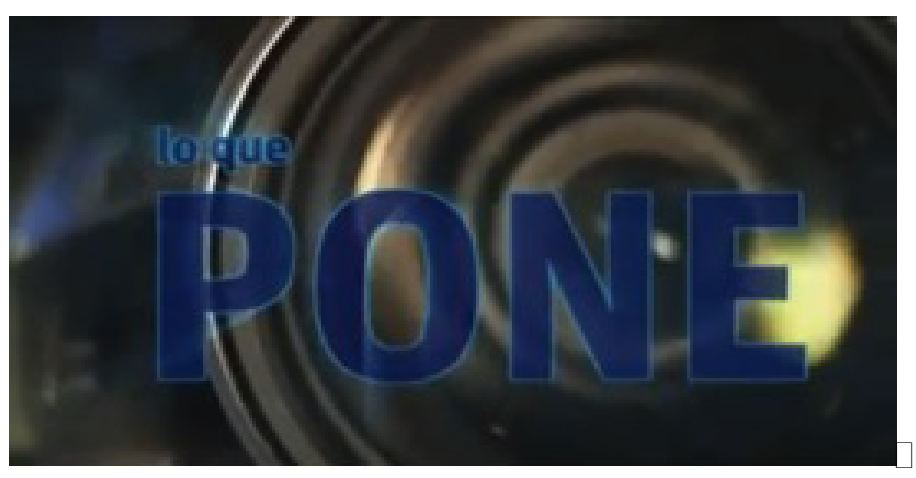

2010 cuota ot pantalu
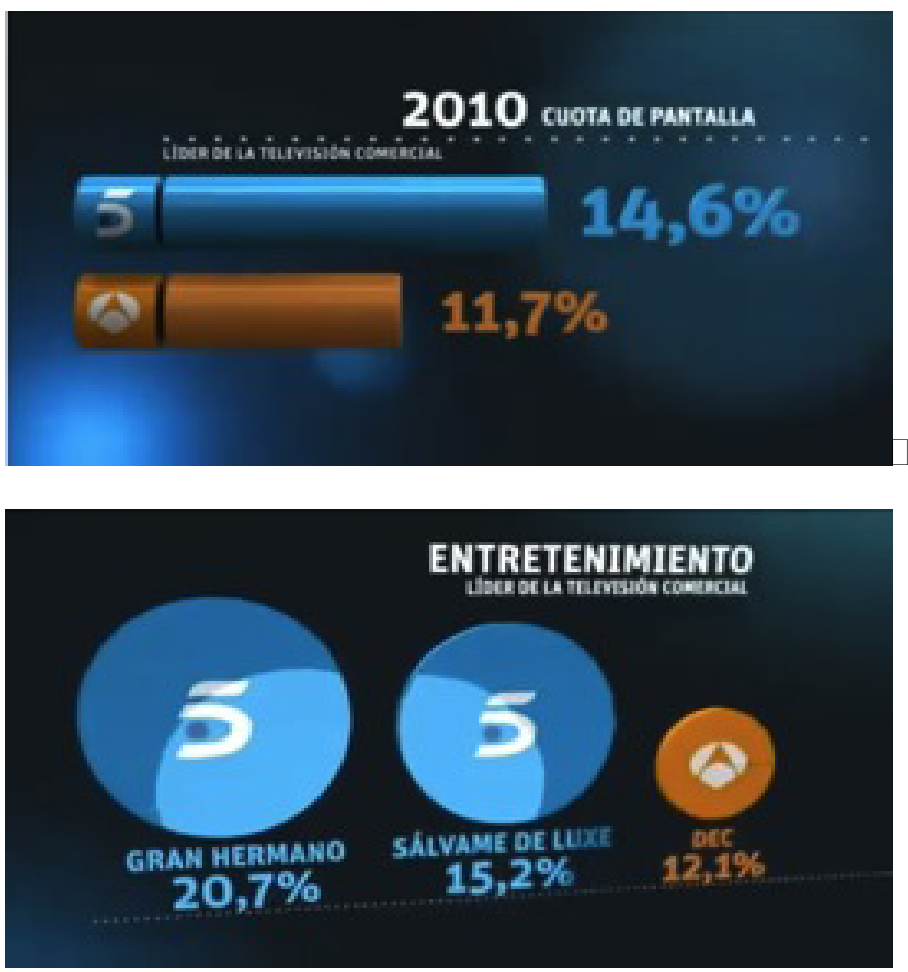
Jessica Fernández Vázquez

Fig. 15. Gráfico en el que Telecinco se declara líder en informativos

Fig. 16. Gráfico en el que Telecinco se declara líder en ficción nacional

Fig. 17. Gráfico en el que Telecinco se declara líder en la franja matinal

Fig. 18. Imagen de la miniserie «Felipe y Letizia»

\section{informativos}

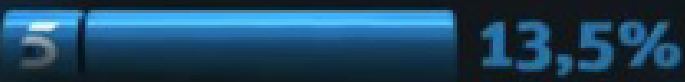

\section{$13,2 \%$}
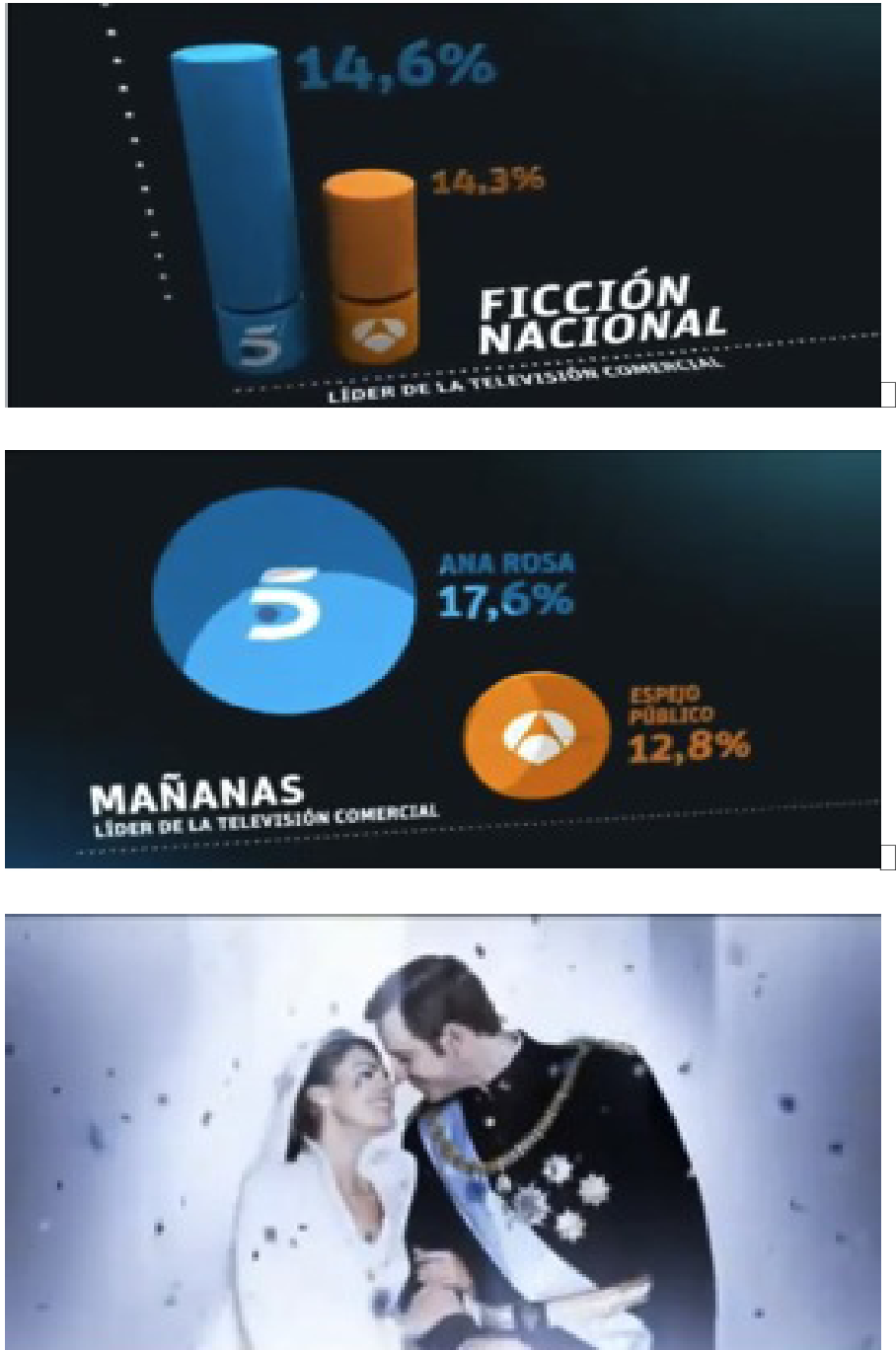

Pensar la Publicidad 


\section{Conclusiones}

Como podemos observar tras el análisis realizado, cada canal basa sus autopromociones en la explotación de una ventaja competitiva, transmitiendo así una clara identidad corporativa: liderazgo en Telecinco y seriedad en Antena 3. Ambos aprovechan este formato publicitario para, por un lado, promocionar en mayor o menor grado sus contenidos y, por otro, atacar a la competencia de forma más o menos explícita, hecho que nos permite comprobar hasta qué punto llega la rivalidad de los canales.

En el caso de Telecinco, existe un claro interés por insistir en la idea de liderazgo, pasando de hacer una autopromoción en la que solo destaca la audiencia de un día a hacer otra en la que se declara líder de todo el año 2010, especificando posteriormente su triunfo en la franja matinal, ficción nacional y entretenimiento, además de dar por supuesto que la cadena es líder en informativos, pero sin mencionar en ningún caso la fuente de la que se extrae el dato.

Parte de la estrategia de Telecinco está basada en informar sobre ese liderazgo mediante gráficos en los que se alude directamente a Antena 3, muchas veces con diferencias abismales entre los tamaños de las barras que los componen cuando en realidad los datos no son tan distantes. De esta forma, las palabras de la voz en off se apoyan en imágenes para insistir en la idea de líder con la que Telecinco quiere asociarse, especialmente en la franja más importante: primetime.

Lo que para Antena 3 entraría dentro del término «telebasura» definido por Elías Pérez ${ }^{33}$, Telecinco lo encuadra en su autopromoción como «entretenimiento», haciendo hincapié en que los espectadores «dejen de lado la tristeza», alusión implícita a la cadena del grupo Planeta ya explicada con anterioridad. Además, se hace con frases de las «promos» del canal rival para elaborar las propias, como es el caso de la palabra «pone» o la «televisión que más gusta».

Por otro lado, la tendencia en las autopromociones de Antena 3 es explotar la ventaja competitiva centrada en poner límites al todo vale, a la lucha por arañar audiencia a cualquier precio y en mostrarse a la audiencia como un canal serio alternativo a la cadena rival, que a su vez se siente aludida con ciertas frases del tipo «será porque no gritamos», «será porque no emitimos lo mismo mañana, tarde y noche», etc. Esta estrategia es cuando menos contradictoria, ya que «la fuerte competencia que comenzaba por el reducido pastel publicitario implicaba la necesidad de producir programas baratos y de gran audiencia ${ }^{34}$, programas que también encontramos en la parrilla de Antena 3. Además, entrando en el juego de las autopromociones, está utilizando las mismas técnicas y de forma semejante al canal del que se quieren diferenciar, porque ambas invaden su identidad corporativa con otro concepto del que en principio quieren escapar: el espectáculo.

\footnotetext{
33 Véase 4.3 .2

34 ELÍAS PÉREZ, C. (2004), op. cit., 28
} 
Ambos canales dan importancia en sus autopromociones a los contenidos informativos, y es que estos son una parte importante de la programación ya que «dan carácter y prestigio. En los informativos se puede ver si una cadena es innovadora, moderna, si tiene méritos ${ }^{35} \gg$. Por lo tanto, ser líder en ellos define la seriedad y confianza puesta por la audiencia en el canal.

En base a esto podemos establecer que la guerra entre Antena 3 y Telecinco se mantiene a día de hoy, ya que sus negocios y por lo tanto sus objetivos siguen siendo los mismos que en sus orígenes, pero agravados por la fragmentación de las audiencias tras el nacimiento de nuevos canales de televisión, impulsados por la digitalización de la señal. Un mayor número de canales, a pesar de que los índices de audiencia demuestran que siguen siendo las cadenas de televisión privada preferidas, implica ofrecer contenidos que atraigan a la audiencia con el fin de lograr y fortalecer el primero de los valores de marca que definíamos al inicio de la investigación: fidelizar al espectador, con el fin de no reducir sus ingresos por publicidad.

Si bien las autopromociones eran una buena estrategia para mostrar parte de estos contenidos, transmitir una determinada identidad y cumplir con la finalidad de atracción, hoy en día, tal y como se comprobó con la presente investigación, este formato publicitario amplió sus horizontes convirtiéndose en una estrategia para desprestigiar al canal rival en lugar de promocionar las parrillas que cada uno ofrece. A través de ellas llegan a hacer ataques frontales para reafirmar la idea de liderazgo o seriedad y posicionarse como la cadena preferida por la audiencia. Estos ataques se vuelven más duros con cada nueva oleada de autopromociones, lo que deriva en que ambos canales se relacionen más con el concepto espectáculo que con los valores que quieren transmitir.

Tras este análisis realizado, comprobamos cómo las hipótesis de partida se confirman: Antena 3 se posiciona como un canal serio y de calidad, mientras que Telecinco encuentra su ventaja competitiva en el liderazgo, utilizando las autopromociones para transmitirlo. Este formato publicitario se ha convertido ahora en uno de los elementos clave para realizar referencias comparativas entre los contendientes, respondiendo a una guerra abierta desde sus orígenes pero en la que el espectador es más consciente que nunca de los ataques intencionados que se envían de un canal a otro.

\section{Referencias bibliográficas}

AAKER, D. (1994): Gestión del valor de la marca. Capitalizar el valor de la marca, Madrid, ediciones Díaz de Santos

ABC, Abc on-line, http://www.abc.es/20101026/tv-series/felipe-hispania-letizia-201010261020. html. Web visitada el 10/02/2011

35 El País, El País online http://www.elpais.com/articulo/Pantallas/MARINAS/_LUIS/ESPANA/TELE_5/informativos/dan/caracter/prestigio/elpepirtv/19931107elpepirtv_1/Tes Web visitada el 20/02/2011 
- http://www.abc.es/hemeroteca/historico-16-04-2004/abc/Comunicacion/aqui-no-hay-quien-vivase-impuso-a-los-serrano-en-una-batalla-sin-reglas-el-virus-esta-de-vuelta $962984461782 . \mathrm{html}$. Web visitada el 10/02/2011

Agencia de Noticias Atlas, Atlas online, http://www.atlas-news.com/info/quien_somos.shtml. Web visitada el 14/02/2011

AIMC. EGM. Estudio General de Medios 1968-1998, Cd-Rom, 6.

Artero MuÑoz, J.P. (2007): Modelos estratégicos de Telecinco (1990-2005), Madrid, Editorial Fragua

BARroso garcíA, J. (2002): Realización de los géneros televisivos, Madrid, Síntesis

Bustamante, E. (1999): La televisión económica. Financiación, estrategias y mercado, Barcelona, Gedisa Editorial.

CORTÉs LAHERA, J.A. (2001): La estrategia de la seducción. La programación en la neotelevisión, Pamplona, Editorial Eunsa

DAFONTE, A (2006): «Construcción de marca en formatos televisivos: los jóvenes como objetivo»,

http://www.unav.es/fcom/cicom/2006/docscicom/4_DAFONTE_GOMEZ.pdf. Web visitada el 10/05/2011.

DANTA, R. (2009): «TV y capitalización del tiempo de ocio. La programación como medio de producción», Revista Latina de Comunicación Social, 64. http://www.revistalatinacs.org/09/art/47_846_ULEPICC_04/39Danta.html. Web visitada el 09/05/2011.

ELÍAS PÉREZ, C. (2004): Telebasura y periodismo. Madrid, Ediciones Libertarias.

El Mundo, El Mundo online, http://www.elmundo.es/elmundo/2006/06/02/comunicacion/1149262300.html. Web visitada el 10/02/2011.

El País, El país online, http://www.elpais.com/articulo/Pantallas/MARINAS/_LUIS/ESPANA/TELE_5/informativos/dan/caracter/prestigio/elpepirtv/19931107elpepirtv_1/Tes. Web visitada el 20/02/2011.

El Semanal Digital, http:/www.elsemanaldigital.com/articulo.asp?idarticulo=107320 $\&$ tema $=\&$ accion $=\&$ mes $=\&$ ano $=$ ref $=$. Web visitada el $10 / 02 / 2011$.

Fórmula TV, http://www.formulatv.com/1,20050111,743,1.html. Web visitada el $7 / 02 / 2011$.

— http://www.formulatv.com/1,20080105,6482,4.html. Web visitada el 10/02/2011.

— http://www.formulatv.com/noticias/16593/audiencias-tierra-de-lobos-arranca-encima-raphael/. Web visitada el 7/02/2011.

— http://www.formulatv.com/noticias/16769/audiencias-el-internado-lidera-holgura-despedida-definitiva/. Web visitada el 7/02/2011.

GuERrero, E. (2010): El entretenimiento en la televisión española. Historia, industria y mercado, Barcelona, Editorial Planeta, colección Deusto-CIEC.

MATEOS-PÉREZ, J. (2008): «La contraprogramación y la desprogramación en España (1989-1994). Definiciones, desarrollo y ejemplos», Historia y comunicación social, 13, http://revistas.ucm.es/inf/11370734/articulos/HICS08081101191.PDF. Web visitada el 10/05/2011.

MEDINA LABERÓN, M. (1998): Valoración publicitaria de los programas de televisión. Pamplona, Ediciones Eunsa.

Muñoz, J.J. (2004): Nuevo diccionario de Publicidad, Relaciones Públicas y Comunicación Corporativa, Buenos Aires, Editorial Libros en Red 
REAL DeCReTo 920/2006, de 28 de julio de 2006. Reglamento general de prestación del servicio de difusión de radio y televisión por cable, http://www.boe.es/boe/dias/2006/ 09/02/pdfs/A31532-31538.pdf. Web visitada el 15/02/2011

REAL DECRETO 1462/1999 de 17 de septiembre de 1999. Reglamento que regula el derecho de los usuarios del servicio de televisión a ser informados de la programación a emitir, http://boe.es/boe/dias/1999/09/29/pdfs/A34660-34662.pdf. Web visitada el 15/02/2011

SÁNCHEZ TENA, J.E; ORTEGA ANGULO, S. (2004): «Incógnitas y contradicciones de la programación», El Anuario de la televisión, 2004, Madrid, GECA.

VALDERRAMA SANTOMÉ, M. (2005): «De la paleo a la neotv a través de la autopromoción y la identidad televisiva: El caso de TVG», Área abierta, http://revistas.ucm.es/portal/ abrir.php?url=http://revistas.ucm.es/inf/15788393/articulos/ARAB0505130004A.PDF. Web visitada el 10/02/2011.

Vertele, http://www.vertele.com/noticias/multa-historica-a-telecinco-por-contraprogramar/. Web visitada el 10/02/2011

VILCHES, L. (1993): La televisión: los efectos del bien y del mal, Barcelona, Ediciones Paidós. 